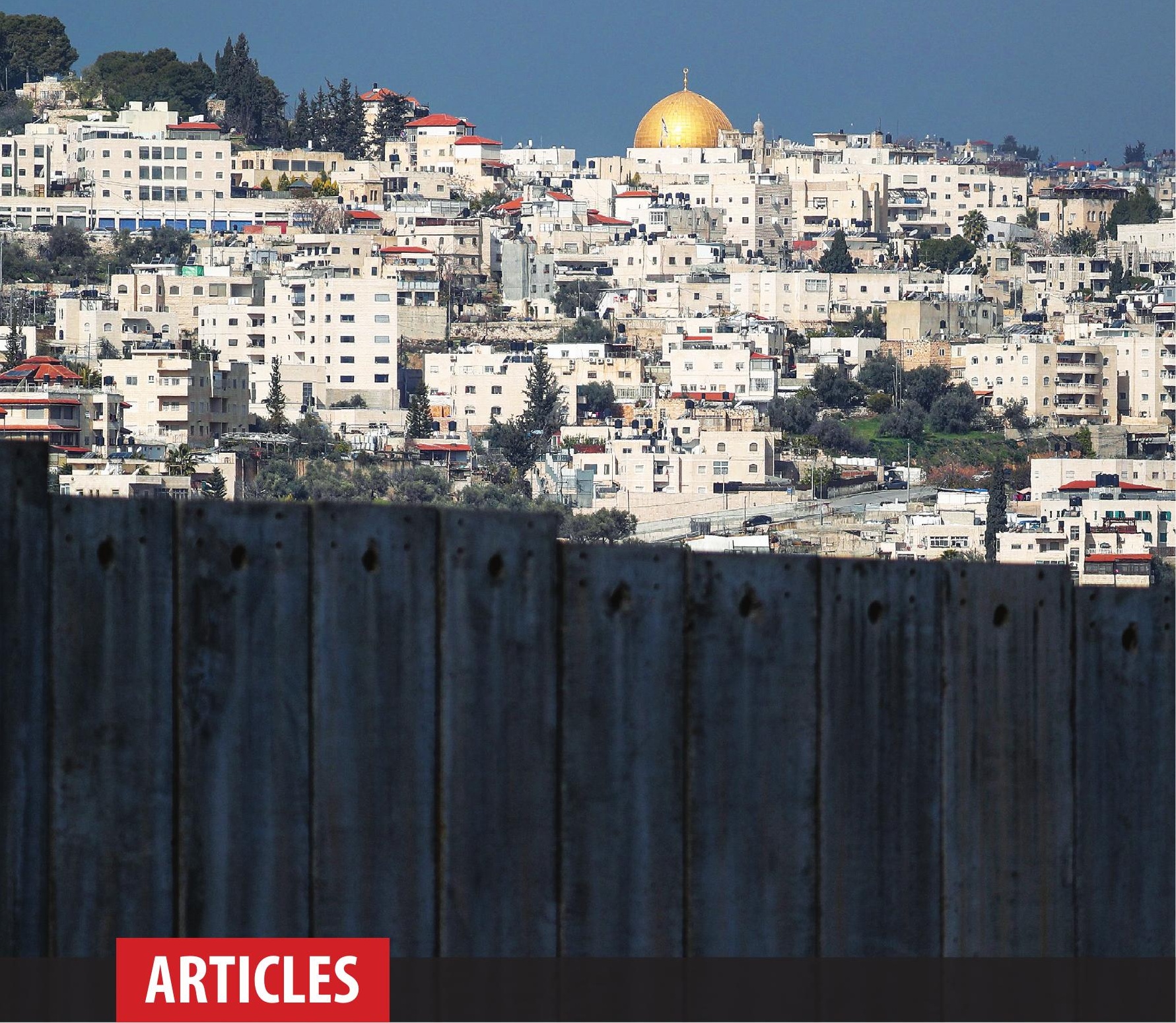

Israel, Palestine, and Apartheid RAN GREENSTEIN

Israeli Practices of Governance in Palestine ELIA ZUREIK

Evaluating Hamas' Struggle in Palestine NASUH USLU and IBRAHIM KARATAŞ

\section{U.S. Policy Toward the Israeli-Palestinian} Conflict under the Trump Administration: Continuity or Change?

AYFER ERDOĞAN and LOURDES HABASH

\section{A Socio-Political Overview of Post-Socialist} Southeastern Europe Today SABRINA P. RAMET
Deconstructing the Gulf Crisis:

Post-Colonialism and Competing 'Projects' in the Middle East FARHAN MUJAHID CHAK

Writing Malaysia and the Moro Identity: An Analysis of the Moro National Liberation Front's Foreign Policy

KRIZZA JANICA MAHINAY

The Paradox of Inclusion/Exclusion of Islamist Parties in Tunisia and Jordan after the Arab Uprisings: A Comparative Study NUR KÖPRÜLÜ 


\title{
Israel, Palestine, and Apartheid
}

\author{
RAN GREENSTEIN \\ University of the Witwatersrand, South Africa \\ ORCID No: 0000-0001-6910-4420
}

ABSTRACT The term 'apartheid' was coined to describe the system of segregation, practiced for many years in South Africa. However, the 2002 Rome Statute of the International Criminal Court omitted all references to South Africa in its definition of 'the crime of apartheid' and the term is now defined globally as a crime against humanity. This article explores the similarities and differences between the now abandoned practice of apartheid in South Africa and the current apartheid policies of Israel, highlighting the need to differentiate between Israel proper (within its pre-1967 boundaries), Greater Israel (within the post-1967 boundaries), and Greater Palestine. Whereas Israel claims to offer democratic rights for all its citizens, all seven pillars of apartheid can be shown to exist in the occupied territories, where the Israeli regime is the sole authority, leaving the Palestinian Authority powerless. The article details how the influx of different immigrant communities to Israel has dispossessed the Palestinians from their land. It provides a new definition for the policies practiced, and the many ways in which Israel dictates the lives of the Palestinians, as 'apartheid of a special type.' It concludes with a proposal to support the policy of bi-nationalism, as stated in in the Haifa Declaration of 2007.

Keywords: Israel, Palestine, Apartheid, Bi-nationalism

Insight Turkey 2020

Vol. 22 / No. 1 / pp. 73-92

Recieved Date: 01/16/2020 • Accepted Date: 02/20/2020 • DOI: 10.25253/99.2020221.06 


\section{Introduction: What Is Apartheid?}

W

hat do we mean when we speak about apartheid? On the face of it the answer is obvious: apartheid was a South African system of social and political domination between 1948 and 1994. During that period government policies imposed conceptual, legal, and geographical distinctions between people on the basis of race. Legislation divided the population into white and black groups, and the latter were further divided into sub-groups. Black African people were classified into ethnic groups, each with its 'own' homeland in which to exercise political rights and meet social needs. At the same time, in the key area of labor, black people worked for and served white people, a principle that shaped economy and society throughout South African history.

In a useful summary, historian William Beinart identified seven pillars of apartheid. None of these were new, but they were tightened and made more difficult to evade with the rise of the National Party to power in 1948: (i) Stark legal definition of races; (ii) Exclusive white participation in and control of central political institutions; (iii) Separate institutions and territories for black African people; (iv) Spatial segregation in town and countryside, (v) Control of the movement of African people into the cities; (vi) Tight division in the labor market; (vii) Segregation of amenities and facilities of all kinds. ${ }^{1}$

Conceptually, apartheid referred to a three-pronged regime combining colonial dispossession, class exploitation, and racial discrimination. Its three core dimensions -land, labor, race- reinforced each other initially, but over time the legal machinery associated with race became an obstacle to socio-economic stability and growth. That machinery was eventually discarded, removing the racial-political logic that made South Africa unique. Inequalities on the basis of land and labor remain central to post-apartheid society, though. It is possible to speak about apartheid today in the social or class sense but not in the racial sense of the past.

Two notable attempts to expand the notion of apartheid beyond South Africa were made: The International Convention on the Suppression and Punishment of the Crime of Apartheid, adopted by the United Nations (UN) in 1973, defined apartheid as "a crime against humanity" and a violation of international law. Apartheid meant "similar policies and practices of racial segregation and discrimination as practiced in southern Africa ... committed for the purpose of establishing and maintaining domination by one racial group of persons over any other racial group of persons and systematically oppressing them."

Moreover, the 2002 Rome Statute of the International Criminal Court omitted all references to South Africa in its definition of 'the crime of apartheid.' In its 
Article 7 on crimes against humanity, the Rome Statute defines the crime of apartheid as "inhumane acts ... committed in the context of an institutionalized regime of systematic oppression and domination by one racial group over any other racial group or groups and committed with the intention of maintaining that regime." These acts include "deportation or forcible transfer of population" and "persecution against any identifiable group or collectivity on political, racial, national, ethnic, cultural, religious, gender ... or other [inadmissible] grounds." Persecution in turn is defined as "intentional and severe deprivation of fundamental rights contrary to international law by reason of the identity of the group or collectivity."

With the passage of time and the unfolding political transition in South Africa, apartheid has acquired a legal meaning that could be applied anywhere, though its association with the historical South African regime remains strong. No other political system has been formally defined as an apartheid state by international bodies. However, adding the international legal dimension to the analysis means we can evaluate the term against that benchmark rather than solely against the practices of pre-1994 South Africa, even though these remain of interest.

\section{What (and Where) Is Israel?}

We need to consider which Israel is our topic of concern: Israel today, a regime which extends from the Mediterranean Sea to the Jordan River or Israel before 1967, along the Green Line? Are the Palestinian territories occupied in 1967 part of it? What about the Palestinian Diaspora? The central question in this respect is the relationship between three components: (i) Israel proper (within its pre-1967 boundaries); (ii) Greater Israel (within the post-1967 boundaries); and (iii) Greater Palestine (a demographic rather than geographic concept, covering all Arabs who trace their origins to pre-1948 Palestine).

It is only by considering the three components together that we can explore fully the meanings of Israeli apartheid. We cannot take for granted realities that became entrenched through conquest and dispossession -the exclusion of the 1948 refugees- and ignore other realities, such as the permanent 'temporary' occupation of 1967, which incorporates land under Israeli control but excludes its Palestinian residents. 


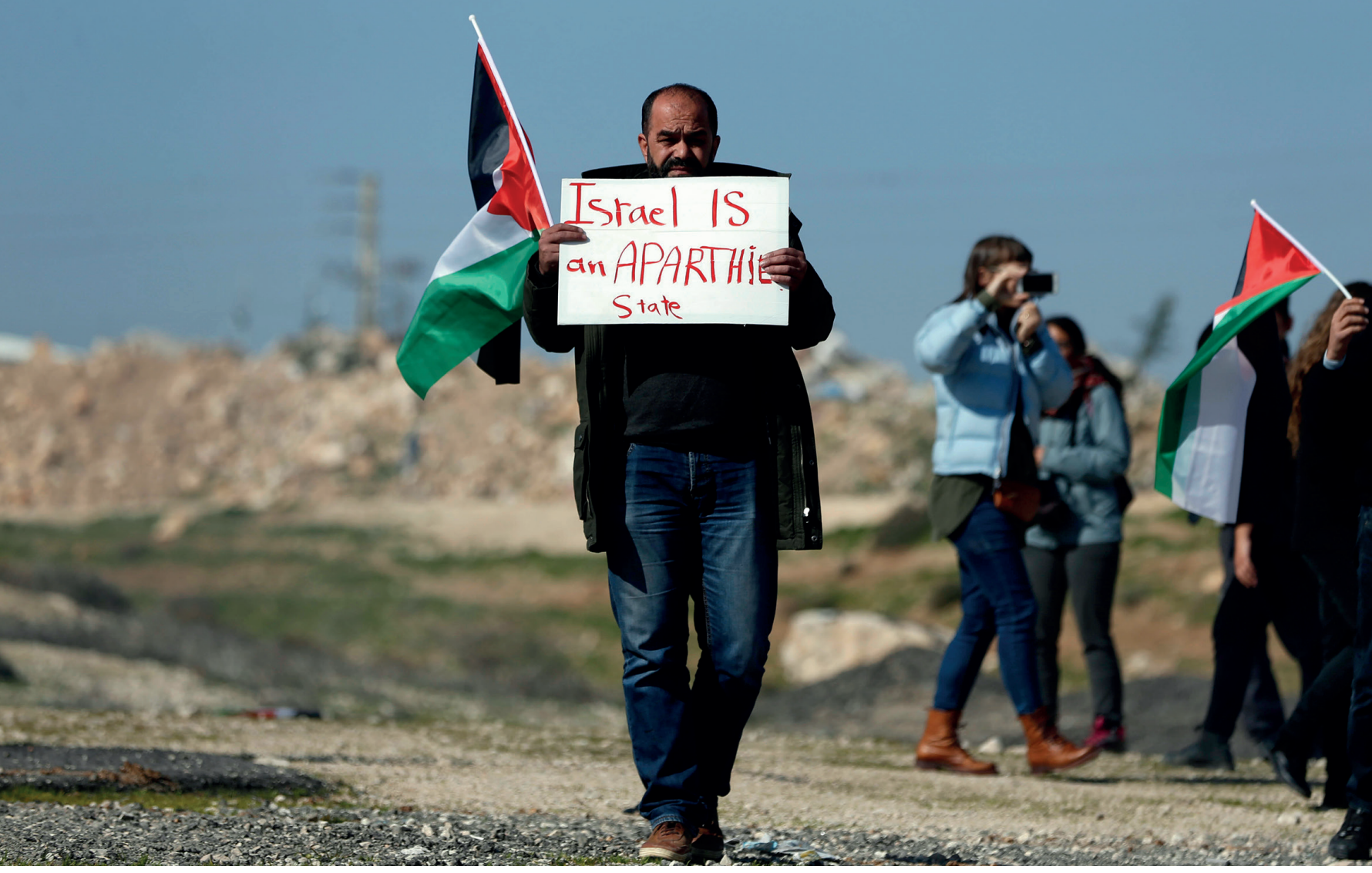

A Palestinian

protestor holds

a banner during

a demonstration

on a road to

Jerusalem,

January 23, 2019.

ABBAS MOMANI /

AFP via Getty Images

\section{Israel Proper}

Israel proper within the Green Line from 1948 to 1967 had a large Jewish majority (80-85 percent of the population) and a Palestinian-Arab minority, an outcome of two combined processes. UN General Assembly Resolution 181 of 1947 partitioned Palestine into Jewish and Arab states. The Jewish state was meant to accommodate 400,000 Arabs, who would have been 45 percent of its population. The bulk of the rest (725,000 Arabs) were to become residents of the Arab state. This plan never materialized. The country was plunged into war that ended with the conquest by Jewish forces of additional territories that had been home to 500,000 Arabs before the war, a figure that would have transformed the Jewish population from a small majority ( 55 percent according to the UN plan) into a minority of 40 percent in their 'own' state. ${ }^{2}$

That prospect - unacceptable from an Israeli-Zionist point of view- led to a campaign of ethnic cleansing. Together with war-related hardships and fears for the future, it resulted in the depopulation of Israeli-controlled territories. At least 80 percent of their Arab residents fled or were expelled in what became known as the Nakba (catastrophe). They were prevented from returning to their homes and have been refugees ever since.

The demographic outcome of the war was a unified and growing Jewish population in the new state of Israel, and a fragmented Palestinian-Arab population, which was dispersed in several territories. About 15 percent of Palestinians remained in Israel and were granted citizenship, including people forced 


\section{In practice, over the last 53 years Israel has kept Arab residents subject to military rule while allowing hundreds of thousands of its own citizens to settle on land confiscated or illegally bought from the original owners}

out of their homes and villages who stayed within state boundaries (known as 'present absentees'). A further 25 percent remained in Palestinian territories occupied by Jordan and Egypt, which became known as the West Bank and the Gaza Strip. The rest -60 percent of the total- were refugees inside Palestine and in neighboring Arab countries.

Only those in the first group -variously referred to as Israeli Arabs or Palestinian citizens or the Arabs of 1948- acquired citizenship rights in their homeland and place of residence. Their rights are real but subject to various qualifications as second-class citizens. Only two of the seven pillars of apartheid identified above by Beinart apply to them (i.e., legal definition of groups and effective spatial segregation). It is crucial to keep in mind though, that this group is a rump community, representing only a segment of the original Arab residents of what became Israel. The rights to which they have access are denied to the majority who hail from there but became refugees in 1948. For this reason, we cannot speak about 'Israel proper' in isolation. It is misleading to discuss any aspect of Israeli ethnic policies and practices in its 1948 territory without realizing that they are all premised on the dispossession of the refugees. The erasure of the legacy of this 'excluded presence' was not a once-off event but is an ongoing project that shapes Israeli practices to this day.

\section{Greater Israel}

Greater Israel came into being with the 1967 occupation of the West Bank and Gaza Strip, which continues to this day though in different ways. These territories have not been formally annexed to Israel but fall under its overall system of control. If the state is a body that claims monopoly on the legitimate use of physical force in a territory, Israel effectively is the only state in the entire area. This means we are looking at a single integrated regime in all the post-1967 territories, even if its rule is applied in an internally differentiated manner.

The Israeli position is that the Palestinian Territories are disputed rather than occupied and will remain so until their final status is decided through negotiations. In practice, over the last 53 years Israel has kept Arab residents subject to military rule while allowing hundreds of thousands of its own citizens to settle on land confiscated or illegally bought from the original owners. Israel has built hundreds of Jewish-only settlements whose residents enjoy cit- 
Israel could acquire a permanent Jewish majority only through an accelerated immigration of Jews into the country and forced departure of non-Jews from the country izenship rights, have access to services funded from the state budget, and are armed and defended by Israeli military. It has constructed segregated roads for its own citizens, built the 'separation fence' (aka Apartheid Wall), erected hundreds of road blocks to restrict the movements of Palestinian residents, and put in place thousands of military regulations that affect the daily lives of local people, their access to resources and services, and their ability to make a living. All seven pillars of apartheid given above as identified by Beinart exist in the occupied territories.

In all these activities the concerns of Palestinian residents are ignored. They have no say in the way in which they are governed by Israel. In most things that matter to their daily lives -land, water, roads, movement between towns and villages, immigration, construction, trade- the Israeli regime is the sole authority, leaving the Palestinian Authority powerless. Although steps undertaken by the regime aim to entrench its control and facilitate the settlement of Jewish civilians, the Israeli courts have routinely endorsed the pretense that these policies are motivated by military needs -the sole grounds permissible in international law. Only in very few cases do the courts challenge the authorities on minor aspects of policy (for example, changing the precise route of the 'separation fence' without challenging the legality of its construction on private land). The Israeli legal system has played a crucial role in making the occupation permanent, while providing it with a (shrinking) fig leaf of legal legitimacy. ${ }^{3}$

Palestinian residents of the 1967 Occupied Territories have no representation in the Israeli state. They live under a regime that systematically separates them from the rights-bearing Jewish citizens of Israel residing in the same territory. It is no wonder that most uses of the apartheid analogy refer to these territories $^{4}$ Glaring legal and social inequalities between citizens and subjects, and the complete lack of interest in gaining the consent of local Palestinians, testify to the exclusionary thrust of its policies. In the initial post-1967 period it focused on entrenching its rule but also attempted to govern the population by showing some concern with its welfare, if only in order to decrease the chances of mass revolt. Since the Oslo Accords of 1993, and especially since the Second Intifada of 2000, it abandoned even this limited concern and moved from 'the colonization principle' -seeking to shape the body- to 'the separation principle' -seeking to crush it. ${ }^{5}$

The notion of 'separation' or segregation (hafrada) does not mean relinquishing domination. Rather it is a new mode of rule aiming to win the 'bride' 
(land) without the 'dowry' (people). This is done not in order to entrench the hegemony of the regime or exploit the labor of the 'natives,' as in apartheid South Africa, but to destroy any political resistance to unfettered Israeli control. ${ }^{6}$

\section{Greater Palestine}

Greater Palestine is the third component of the situation, at once the most neglected and the most critical for understanding the origins and nature of the Israeli regime. It is an essential component precisely because it is absent from mainstream political discourse. Most people writing about Israeli society would likely be surprised to see this concept treated as internal to it. What is the rationale for including it here? From its inception the regime has been based on an exclusionary imperative, of which Greater Palestine is the outcome. It is the mirror image of the Zionist vision of the 'Ingathering of the Exiles': the gathering of Jews in Israel has been accompanied by the dispersal of Palestinians into the Diaspora. These two processes not only coincided in time but are causally related: Israel could acquire a permanent Jewish majority only through an accelerated immigration of Jews into the country and forced departure of non-Jews from the country.

This feat was realized in the course of the 1948 War, and it had to be reinforced repeatedly. In the course of the 1950s the physical remains of Palestinian homes and villages were systematically destroyed, their property confiscated, their land allocated to Jewish agricultural settlements, and their abandoned urban neighborhoods became populated with immigrants from Middle Eastern and Eastern European countries. Arab names disappeared from official maps though at times continued to live on in popular culture. The remaining Palestinian citizens were cut off from their ethnic kin and the broader Arab world. A new 'Israeli Arab' identity was imposed on them, all in order to erase all traces of pre-1948 Arab Palestine.

However, the 1967 War reunited Palestinian citizens with part of their people from whom they had been separated. Together with the rise of resistance organizations based among refugees in Lebanon, Jordan, and Syria, it revived Palestinian nationalism as a movement seeking to represent all segments of the population of Greater Palestine, despite their diverse conditions of existence. In response, the regime intensified efforts to relegate the refugees into the dustbin of history (as active agents), while highlighting their demands for return which would mean 'the destruction of Israel.'

It is this last element that makes the Israeli regime unique. It is not exercising control and competing for domination in its own territory only. It has to reassert its power in relation to an extra-territorial population, whose legitimacy and potential presence must be suppressed. Any recognition accorded to it, 
even limited and symbolic, would constitute a mortal threat to the regime. Not in an immediate sense but as a portent of a future fearfully imagined as a sudden uncontrolled influx of the undesirable masses. This specter haunting Israeli-Jewish society affects policies undertaken towards Palestinians. Intensified efforts to prevent mention of the 'original sin' of the Nakba by prohibiting public acts aimed to retain its memory, penalizing financially bodies that organize commemorative events, and purging dissent from textbooks, are evidence that the issue remains alive in the consciousness of parties to the conflict.

This challenge is compounded by another extra-territorial population, that of Jewish people (in the plural). Israel is defined not as a state of all its citizens but rather the state of 'a People' (in the singular) dispersed in different places but destined to return to its ancestral home. The notion of 'return', applied to people who never set foot in the territory, they and their ancestors, for millennia, if they ever did, is unique. Few other states maintain links with Diaspora communities and recognize people who can trace their origins to concrete families and regions that their ancestors had left a century or two ago. Similarly, Palestinian refugees talk about a return to a place where they or their immediate ancestors used to live. In many cases they can point to specific houses that belonged to their families. The historical links they invoke are concrete. That is not the case for the Return to Zion: not a single Jewish immigrant to Israel/Palestine since the emergence of Zionism 140 years ago could ever establish specific links to any place in the country, piece of land, or property that belonged to any known ancestors. The relationship is abstract and ideological -relating to the state as a political concept- rather than concrete and personal.

Many critical scholars agree that it is impossible to look at Israel proper in isolation from Greater Israel. ${ }^{7}$ They regard the latter as the effective boundary of control and meaningful unit of analysis. However, very few discuss Greater Palestine as part of the picture since it lies beyond the pre-1948 boundaries. In fact, precisely how Palestinians from the 'beyond' came to occupy that position and have been kept there against their will -the process of ethnic cleansing- is a crucial element of the system of control which must be reintroduced into the analytical framework. The thorough exclusion of Palestinians in the Diaspora makes the application of Beinart's pillars a moot point: they are so totally outside the boundaries of the system that 'apartheid' would constitute progress from their position.

That said, clearly the conceptual distinction between Israel and the Occupied Territories is still deeply entrenched. This is a testimony to the success of the Israeli strategy of excluding occupied Palestinians from its body politic while retaining effective control over them. At the same time it is also a testimony to 
the spirit of nationalist resistance to the 1967 occupation, and the struggle for equal rights by Palestinian citizens of Israel. Despite their common themes these struggles have been waged so far as separate, even if related, campaigns, thus reinforcing the distinction between the different components of the situation.

\section{What Is the Regime?}

The discussion so far has referred to the agency of the Israeli regime, which is frequently linked to the notion of Zionism. What is Zionism though? An ideology, a political movement, a program of action, or an umbrella term referring to a common theme found in state practices? A bit of a historical background is in order.

The Zionist movement emerged in Central-Eastern Europe in the late $19^{\text {th }}$ century, targeting Palestine

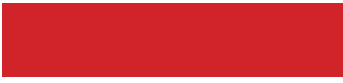

The center of power within the Jewish community shifted inexorably away from the world Zionist movement towards the emerging local civilian and military statelike institutions dominated by the Labor movement (Eretz Israel) as a destination for Jewish immigration and land settlement, and eventually independent statehood. It remained a minority tendency among Jews, most of whom chose to immigrate to the West, primarily to the United States, stayed put in their own countries, or joined political movements acting to protect their rights and change society from within. The movement received a major boost in 1917 when the British Government, whose military forces gaining control over Palestine, issued the Balfour Declaration. The British recognized the movement and its aspiration to establish a 'national home' for Jews, a phrase left deliberately vague in order not to imply direct support for a Jewish state in the country.

With the Declaration, the relations between Jewish settlers and indigenous Arabs acquired an explicit political dimension. The Zionist movement started to play a key role in representing the organized Jewish community in the country, and in facilitating further immigration, land purchases, and settlement. At the same time, the local settler community took the initiative in building up military forces and shaping the development of the Jewish-dominated economic sector. The institutions governing the concrete activities of the settlers -the labor movement, municipal councils, business associations- were dominated by structures based within the country. The Zionist movement continued to play an important role on the diplomatic scene, and in raising funds, but its power vis-a-vis local constituencies gradually diminished. 


\section{'Apartheid of a special type' - a regime not easily captured in a concise trendy term, because it combines democratic norms, ethnic hierarchy, military occupation, and exclusion/ inclusion of extra-territorial populations}

Zionism as an ideology was a common denominator of most political forces taking part in the life of the organized Jewish community before 1948. The concrete meanings of its tenets varied: different interpretations and priorities ensued from the same set of general principles. Regardless of internal ideological debates, the center of power within the Jewish community shifted inexorably away from the world Zionist move-

ment towards the emerging local civilian and military state-like institutions dominated by the Labor movement, associated above all with the person and policies of David Ben-Gurion. These institutions determined policies towards Palestinians, were in charge of the military campaign that led to the Nakba, and subsequently became 'the regime' after 1948. Israeli state institutions shaped relations with Palestinians in their different locations until 1967 and implemented the policies of settlement and control of the Occupied Territories ever since.

All this is to say that the focus of concern here is Israeli state practices, not an abstract entity called 'Zionism.' Those who design and carry out apartheid-like policies are Israeli officials (as well civil society activists), rather than 'the Zionists.' Their system of self-justification as well as dissemination of the 'party line' is Israeli hasbara rather than Zionist ideology, and so on. The object of inquiry is the Israeli regime: a concrete entity with clearly-identifiable civil and military institutions, officials, and regulations. ${ }^{8}$

\section{Apartheid of a Special Type}

If we use the legal definition of apartheid, and thereby de-link the notion from its specific South African history, we may still find it useful at times to use South Africa as a benchmark in order to highlight crucial features of the Israeli regime. Back in the early 1960s, the South African Communist Party coined the term 'colonialism of a special type' to refer to the prevailing apartheid system that combined the colonial legacies of racial discrimination, political exclusion, and socio-economic inequalities, with political independence from the British Empire. Its locus of control was internal to the country rather than external to it as in 'classical' colonial rule. This concept was used to devise a strategy of political struggle that treated local whites as potential allies, not as invaders to be removed from the territory ${ }^{9}$. Making analytical sense of apartheid there was relatively straightforward since it was an integrated system of 


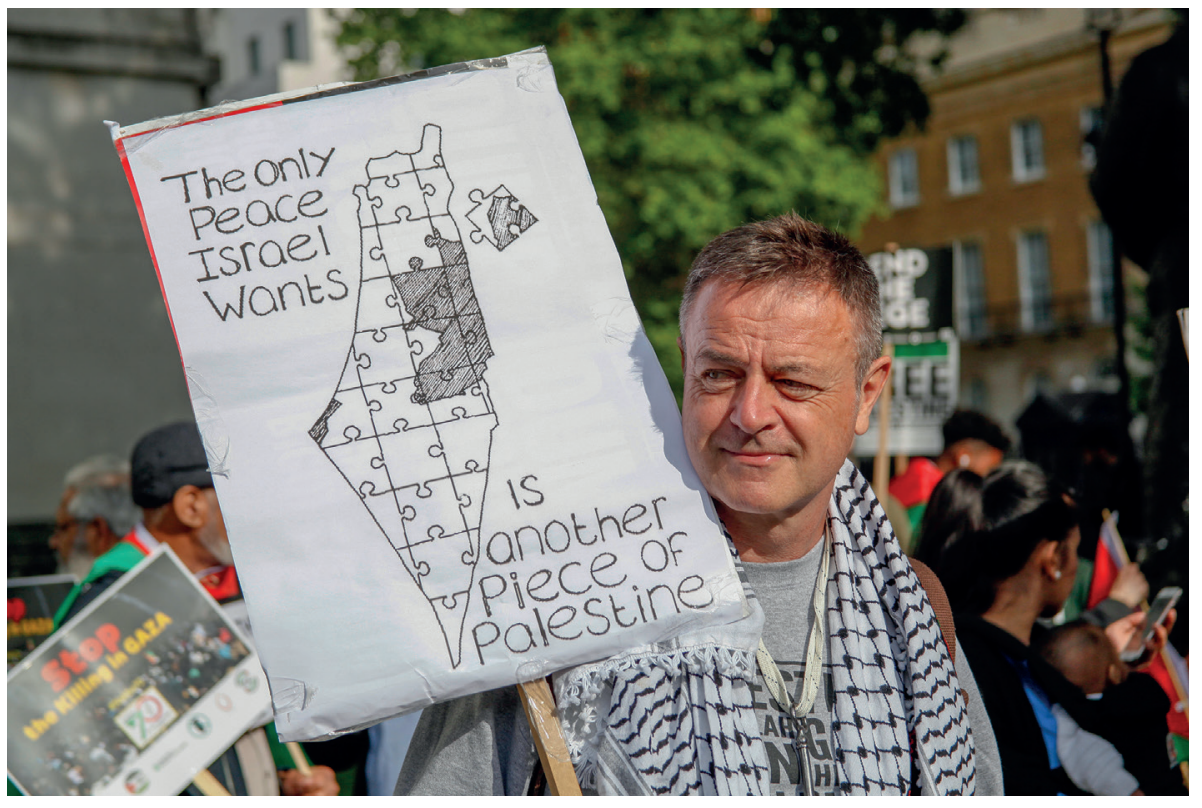

legal-political domination. Different laws applied to different groups of people but there clearly was a single source of authority and an explicit grand design behind it, presented in unapologetic terms.

Making sense of the ways in which the concept of apartheid applies in Israel/ Palestine is more complicated. The degree of legal-political differentiation is greater, as it includes an array of formal and informal military regulations in the Occupied Territories, and policies delegating powers and resources to nonstate institutions (Jewish Agency, the Jewish National Fund), that act on behalf of the state but are not open to public scrutiny. The gap between the formal language of rule, especially as used for external consumption, and practices on the ground is big. That much of the relevant legal apparatus applies beyond Israeli boundaries (to Jews, all of whom are regarded as potential citizens, and to Palestinians, all of whom are treated as prohibited persons), adds another dimension to the analysis. For this reason, I refer to 'apartheid of a special type' - a regime not easily captured in a concise trendy term, because it combines democratic norms, ethnic hierarchy, military occupation, and exclusion/inclusion of extra-territorial populations.

\section{What Are the Main Characteristics of This Regime?}

It is based on an ethno-national distinction between Jewish insiders and Palestinian-Arab outsiders. This distinction has a religious dimension -the only way
A pro-Palestinian protester condemning Israeli occupation, London, UK, June 5, 2018.

CAVENDISH / NurPhoto via Getty Images 


\section{Having put greater emphasis on the traditional Jewish components of identity, at the expense of the more secular components associated with Ashkenazi liberal elites, the Right gradually managed to gain the support of Mizrahim}

to join the Jewish group is through conversion- but is not affected by degree of religious adherence. Secular, traditional, reform, orthodox Jews are equally eligible for membership.

It is important to consider internal distinctions within each of these groups. All Jewish residents of Israel have access to full-fledged citizenship and associated rights. At the same time, there is an informal ethnic hierarchy that divides Jewish citizens into two large groups: the first is Ashkenazim of Eastern European ancestry, historically the dominant group politically, socially, and culturally. The other group is Mizrahim ('Orientals', people hailing from the Middle East and North Africa), brought to Israel in the 1950s to fill in gaps left by the Nakba of 1948, to serve as labor power, cannon fodder, and demographic ballast. To gain recognition as legitimate members of the dominant group they had to leave their Arab and regional heritage behind. Cultural disadvantage -they were regarded by Ashkenazim as primitive, lacking culture and education- combined with material deprivation and social discrimination to make them easy to control initially. They were sent to remote areas along the borders, subject to inferior education and fewer opportunities to find decent employment, and largely restricted to 'development towns,' created as new industrial zones relying on cheap labor, and poor neighborhoods in cities whose Arab residents had become refugees.

Although their living conditions placed them next to Palestinian citizens in the bottom rungs of Israeli society, they had one precious asset the others lacked -Jewish identity, which entitled them to formal political equality. Focusing on what they shared with other Jews while distancing themselves from what set them apart and brought them closer to the enemy -their largely-Arab cultural background-made perfect sense. At some points during the early decades an alliance between some forces within these marginalized groups seemed possible, but it never materialized ${ }^{10}$. The Black Panthers activists of the 1970s and the Democratic Mizrahi Rainbow intellectuals of the 1990s were hesitantly exploring such a move, campaigning on socio-political issues common to Mizrahim and Palestinians, but their bases did not go along with that and they remained isolated. ${ }^{11}$

Mizrahi identity thus developed as a coping strategy to deal with social marginalization with an emphasis not on equality as such but on acquiring an equal share in Jewish privilege, and by implication in the apartheid regime. The deep resentment against the Labor establishment that humiliated and marginalized 
them was translated into a transfer of political allegiance to the right wing Likud alternative, led by Menachem Begin. Having put greater emphasis on the traditional Jewish components of identity, at the expense of the more secular components associated with Ashkenazi liberal elites, the Right gradually managed to gain the support of Mizrahim. The result was the 1977 upheaval that brought Likud to power and made it the dominant force in Israeli politics ever since.

In subsequent years the Mizrahi support for the Right had been consolidated, expressed in the rejection of policies and discourses associated with liberal Ashkenazi elites accused of caring more for 'outsiders' like Palestinians and refugees than for their 'own' people. These elites lost political power but retained a dominant position in the media, academia, culture, and the legal system. Transforming these spheres and demoting the old elites became a goal common to many Mizrahi activists, the nationalist Right, and the settler movement, although they came at the issue from different directions. Reinforcing the Jewish nature of the state against notions like universal human rights, civil equality, and Western-style democracy, which threaten to make Israel into a 'normal' state, has become the unifying battle cry in this campaign.

The distinction between full-fledged Jewish citizens and the rest of the population has been used to expand citizenship beyond Israeli territory, potentially to all Jews, and to limit citizenship within it: Palestinian residents of the Occupied Territories have no citizenship and cannot become citizens. Thus, the regime is open to all non-resident members of one ethno-national group, wherever they are and regardless of their personal history or actual links to the territory. It is closed to all non-resident members of the other ethno-national group, wherever they are and regardless of their personal history or actual links to the territory.

It is a regime based on blurring physical boundaries. At no point in its 72 years of existence have its boundaries been fixed by law, nor are they likely to become fixed in the foreseeable future. Its boundaries are permanently temporary, as evidenced by continued talk of the 1967 occupation as temporary, even though it has already long outlived South African apartheid, which effectively lasted only 42 years. These boundaries are asymmetrical: porous in one direction, allowing the expansion of military forces and settlers into neighboring territories, and impermeable in another direction. It imposes severe restrictions on entry of Palestinians from the Occupied Territories and a total prohibition on those from the Diaspora.

It combines different modes of rule: civilian authority with all the institutions of a formal democracy within the Green Line, and military authority without democratic pretensions beyond the Line. In times of crisis, the military mode 
of rule tends to spill over into the Green Line to apply to Palestinian citizens. At all times, the civilian mode of rule spills over beyond the Green Line to apply to Jewish citizens residing there. The distinction between the two sides of the Green Line is gradually eroding as a result, and norms and practices developed under the occupation filter back into Israel proper: as the phrase goes, the 'Jewish democratic state' is 'democratic' for Jews and 'Jewish' for Arabs.

It is in fact better defined as a 'Jewish demographic state.' Demography -the fear that Jews may become a minority- is the prime concern behind the policies of mainstream forces. All state structures, policies, and proposed solutions to the Israeli-Palestinian conflict are geared, in consequence, to meet the need for a permanent Jewish majority exercising political domination in the State of Israel in whichever boundaries it adopts as definite.

\section{How Do These Compare with Historical South African Apartheid?}

Two key points stand out here. The first is that the foundation of apartheid was a racial distinction between white and black people rather than an ethno-national distinction. Racial groups were internally divided on the basis of language, religion, and ethnic origins, and externally linked in various ways across the color line. This can be contrasted with Israel/Palestine in which lines of division usually overlap. Potential bases for cross-cutting affiliations that existed early on -i.e. anti-Zionist orthodox Jews, Arabic-speaking Jews, indigenous Palestinian Jewish communities- were undermined by the rise of the Zionist movement and Arab nationalism to a dominant position in the course of the $20^{\text {th }}$ century. This left no space for those straddling multiple identities.

One crucial exception must be considered: Palestinian citizens are positioned in between Jewish citizens and Palestinian non-citizens. They are the only segment of the population of Greater Israel that is fully bilingual, familiar with political and cultural realities across the ethnic divide, with enough freedom to organize but not enough rights to align themselves with the oppressive status quo. As a minority group (15-20 percent of Israeli citizens and of Palestinian Arabs) they cannot drive change on their own but may act as crucial catalysts for change.

The second point is that under South African apartheid a key goal of the state was to ensure that black people performed their role as providers of labor, without posing difficult social and political demands. The strategy used for that focused on externalizing them. Although they were physically present in white homes, factories, farms and service industries, they were absent, po- 
litically and legally, as rights-bearing citizens. They were expected to exercise their rights elsewhere. Able-bodied blacks were supposed to commute -daily or monthly and even annually, depending on the distance- between the places where they had jobs but no political rights, and the places where they had political rights but no jobs.

This system of migrant labor opened up a contradiction between political and economic imperatives. Apartheid broke down families and the social order, hampered efforts to create a skilled labor force, reduced productivity, and gave rise to crime and social protest. To control people's movements, it created a bloated and expensive repressive apparatus, which put a constant burden on state resources and capacities. Domestic and industrial employers faced increasing difficulties in meeting their labor needs. From an economic asset (for whites) it became an economic liability. It simply had to go.

In contrast, the economic imperative of the Israeli system has been to create employment for Jewish immigrants. Palestinian labor was used by certain groups at certain times but it was never central to Jewish prosperity in Israel. After the outbreak of the first Intifada in the late 1980s, and under conditions of globalization, it could be replaced by politically unproblematic Chinese, Turkish, Thai, and Romanian workers. The externalization of Palestinians, through denial of rights, ethnic cleansing and 'disengagement', has presented few economic problems for Israeli Jews. There is little evidence of the contradiction between economic and political imperatives that undermined apartheid South Africa.

In summary then, Israeli apartheid of a special type is different from historical apartheid in South Africa in two major respects. First, it is based on consolidated and impermeable ethno-national identities, with few cross-cutting affiliations across the principal divide in society. Second, it is relatively free of economic imperatives that run counter to its overall exclusionary thrust, because it is not dependent on the exploitation of indigenous labor. In both these respects it is a system that is less prone to an integrative solution along the lines of post-apartheid South Africa. At the same time, it is subject to contradictions of its own, which are crucial to its dynamics and present potential opportunities for change.

Its foundational act of ethnic cleansing left behind a weak and disorganized minority Arab group. With Palestinians no longer being a demographic 


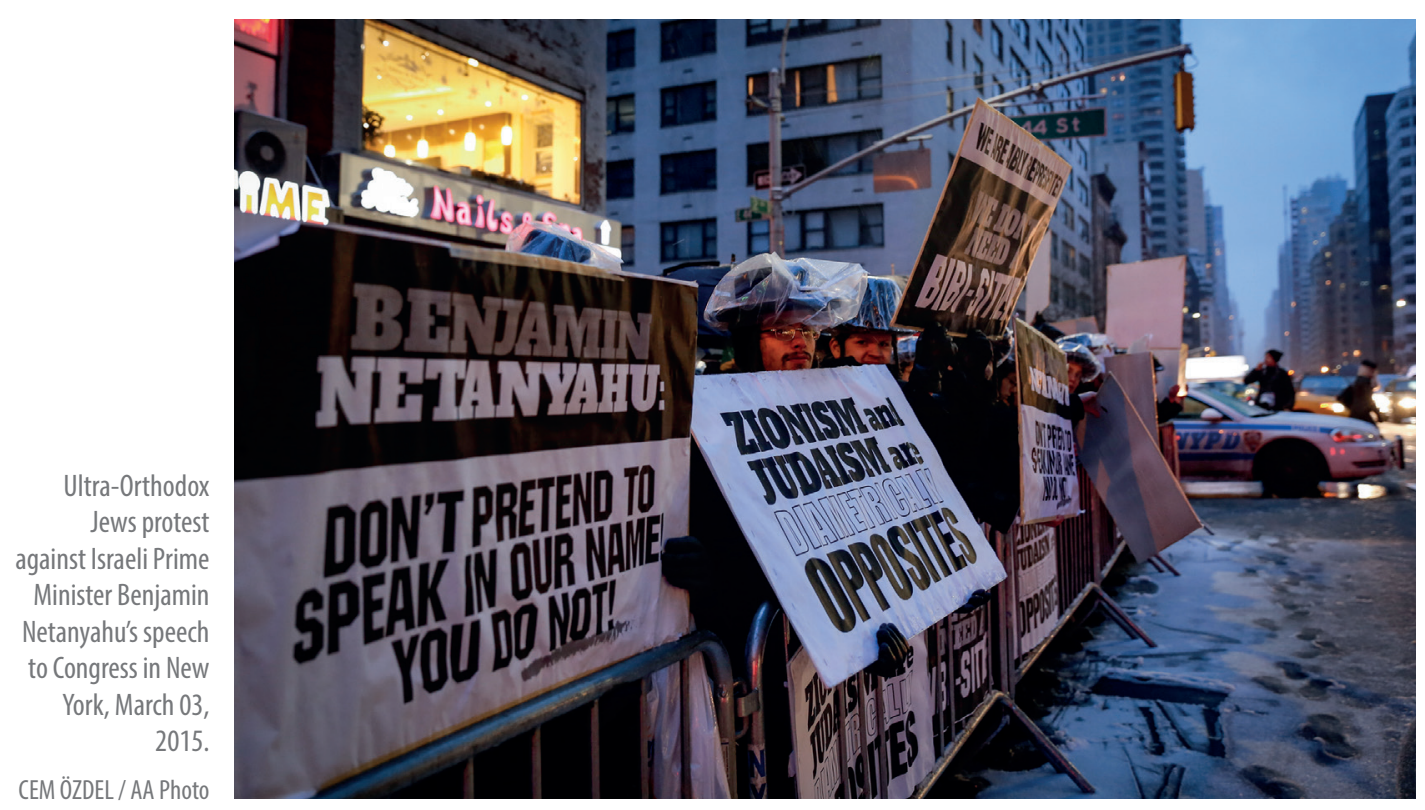

threat, the remaining community could be incorporated into the political system which displayed many of the characteristics of a normal democracy. Its members used this to re-organize and build a solid foundation for resistance politics, combining parliamentary and protest activities that have challenged Israel's exclusionary structures from within. This strategic location has given them a useful vantage point from which to play a vanguard role in the struggle to transform the system.

\section{Conclusion: What Is to Be Done?}

In Israel/Palestine there are two ethno-national groups: Israeli Jews, who are unified by their legal status as full citizens, and Palestinian Arabs, who are divided by their legal status into citizens in Israel proper, resident non-citizens in Greater Israel, and non-resident non-citizens in Greater Palestine. The two groups are distinct by virtue of their language, political identity, religion, and ethnic origins. Only about 10 percent of them (i.e., Palestinian citizens) are fully bilingual. Many Jews have Arab cultural origins, but that legacy was erased through three generations of political and cultural assimilation. The delusion that they could share political consciousness -even if in a dormant form- with Palestinians, must be laid to rest.

Under these circumstances, the South African post-apartheid rainbow nation, based on the multiplicity of identities and the absence of a single axis of divi- 
sion to align them all - unity in diversityis unlikely to be replicated in Israel/Palestine. Elements such as the use of English as the dominant medium of political communication and Christianity as a religious umbrella for the majority of people from all racial groups do not exist in Greater Israel/Greater Palestine. At the same time, if we look only at 'Israel proper,' people of all backgrounds -veteran Ashkenazi and Mizrahi Jews, new Russian and Ethiopian immigrants, and Palestinian citizens- use Hebrew in their daily interaction and largely share similar social and cultural tastes. In mixed towns, such as Haifa, Jaffa, and Acre, there are neighborhoods in which Jews and Arabs live together with little to distinguish between their life styles except for their home language and religious practices.

Of course, we cannot look at life styles, despite their linguistic and religious differences. What we can do is use these emerging realities to build a foundation for a new political perspective, that of bi-nationalism. Bi-nationalism is an approach based on the recognition that two ethno-national groups live together in the same country, separately within homogenous villages and towns in some areas, but also mixed to varying degrees in other areas. Historical patterns of demographic engineering that resulted in forced population movement and dispersal (the $1948 \mathrm{Nakba}$ and the post-1967 settlement project) have created a patchwork quilt of mono-ethnic and bi-ethnic regions, separated by political intent rather than by natural or geographical logic.

Acknowledging this bi-national reality is a call to base any future political arrangement on the need to accommodate members of both groups as equals, at both individual and collective levels. In the words of radical Jewish activists who put together the 2004 Olga Document, "this country belongs to all its sons and daughters-citizens and residents, both present and absentees (the uprooted Palestinian citizens of Israel in 48') -with no discrimination on personal or communal grounds, irrespective of citizenship or nationality, religion, culture, ethnicity or gender." 12

At the same time, we must recognize that people seek incorporation as individuals and as groups. In the Vision Documents, a series of proposals and statements written by academics, intellectuals and activists representing the Palestinian-Arab minority in Israel, the quest for equality is combined with the quest for recognition as a national collective. For example, in the Haifa Declaration of 2007 they call for a "change in the definition of the State of Israel from a Jewish state to a democratic state established on national and 


Palestinians have been
deprived of the most
important weapon used by
black South Africans in their
anti-apartheid struggle,
which was their strategic
location in the economy and
their ability to use the threat
of withdrawing their labor
and disrupt the daily lives
of white citizens, as a crucial
political lever

civil equality between the two national groups, and enshrining the principles of banning discrimination and of equality between all of its citizens and residents." ${ }^{13}$

This approach leads to the removal of "all forms of ethnic superiority; be that executive, structural, legal or symbolic," and the adoption of "policies of corrective justice in all aspects of life in order to compensate for the damage inflicted on the Palestinian Arabs due to the ethnic favoritism policies of the Jews." ${ }^{14}$ Democratizing Israel in this way is important in its own right and also as a way to reinforce other campaigns. If Palestinian citizens are no longer ostracized as illegitimate actors, the struggle against the occupation would receive a big boost by escaping the confines of the progressive Jewish left.

Making Israel proper a state of all its citizens would not change the boundaries of political sovereignty, would have no demographic implications, and would require no negotiation with external forces. It would be a process carried out entirely by citizens. Making Greater Israel a state of all its residents, and establishing common citizenship, is different. It would mean a fundamental change in the boundaries of citizenship, requiring a radical re-alignment of the political scene. It is not feasible in the short term as there are no serious political forces advocating it at present, and it cannot be seen as a substitute for the ongoing struggle against the 1967 occupation.

There is no doubt that the occupation is the biggest festering sore in Greater Israel. Futile negotiations over the last two decades have led to its intensification rather than mitigation. The only way forward is an ongoing campaign to put an end to the occupation, which manifests itself in the daily life of the population in numerous ways (both in Gaza and the West Bank, though differently). Wherever the occupation operates it gives rise to localized resistance. Strategically it is important to de-link the struggle against the occupation from the state of negotiations between Israel and the Palestinian Authority (or Hamas for that matter).

The dimension of Greater Palestine -refugees and their rights- is the most challenging to the boundaries of citizenship and control. It can be resolved only in a staggered manner. First, the present absentees -about 25 percent of 
the Palestinian population in Israel itself who were removed from their original homes in 1948 but have become citizens- must be allowed access to their property and confiscated land. This would involve changes in citizenship status. Second, the original 1948 refugees could be invited back: only about 50,00075,000 of them are still alive, a small number that could be accommodated logistically with ease (an addition of 1 percent to the population). Estimates are that only about 10 percent of them are likely to exercise the right of return, but the matter would require educational, political and legal campaigns. The right of return is vested in individuals who are the only ones who can negotiate on their own behalf. ${ }^{15}$

It is this issue, above all, that makes Israeli apartheid special and more difficult to overcome. As a result of that, Palestinians have been deprived of the most important weapon used by black South Africans in their anti-apartheid struggle, which was their strategic location in the economy and their ability to use the threat of withdrawing their labor (in other words, strike) and disrupt the daily lives of white citizens, as a crucial political lever. Due to the exclusionary thrust of the regime, they operate largely outside the boundaries of the Israeli economic system.

This exclusion is not complete. It does not apply to Palestinian citizens and to a minority among West Bank residents but applies in Gaza and fully in Greater Palestine. Those excluded in that way can exert pressure from the outside, using protest, diplomacy, and violence, but they lack a meaningful strategy of change from within. In this respect, they must combine their efforts with forces internal to Israel (Palestinian citizens together with progressive Israeli Jews), and other regional international actors. Solidarity campaigns and educational efforts are crucial here. Only by making progress on all three fronts together can the overall question of apartheid come to a successful conclusion.

\section{Endnotes}

1. William Beinart, Twentieth Century South Africa, (Oxford: Oxford University Press, 2001), p. 148.

2. Walid Khalidi, "Revisiting the UNGA Partition Resolution," Journal of Palestine Studies, Vol. 7, No. 1 (Autumn 1997), pp. 5-21.

3. Noura Erakat, Justice for Some: Law and the Question of Palestine, (Stanford, CA: Stanford University Press, 2019); Aeyal Gross, The Writing on the Wall: Rethinking the International Law of Occupation, (Cambridge: Cambridge University Press, 2017).

4. Jimmy Carter, Palestine: Peace Not Apartheid, (New York, NY: Simon and Schuster, 2006); "Occupation, Colonialism, Apartheid? A Re-assessment of Israel's Practices in the Occupied Palestinian Territories under International Law," The Human Sciences Research Council, (May 2009), retrieved from http://www. alhaq.org/attachments/article/236/Occupation_Colonialism_Apartheid-FullStudy.pdf; John Dugard, Confronting Apartheid: A Personal History of South Africa, Namibia and Palestine, (Johannesburg: Jacana Media, 2018).

5. Neve Gordon, Israel's Occupation, (Berkeley, CA: University of California Press, 2008). 
6. Eyal Weizman, Hollow Land: Israel's Architecture of Occupation, (London: Verso, 2007); Adi Ophir, et al., The Power of Inclusive Exclusion: Anatomy of Israeli Rule in the Occupied Palestinian Territories, (New York, NY: Zone Books, 2009); Avi Raz, The Bride and the Dowry: Israel, Jordan, and the Palestinians in the Aftermath of the June 1967 War, (New Haven: Yale University Press, 2012).

7. Ariella Azoulay and Adi Ophir, The One-State Condition: Occupation and Democracy in Israel/Palestine, (Stanford, CA: Stanford University Press, 2012).

8. Oren Yiftachel, Ethnocracy: Land and Identity Politics in Israel/Palestine, (Philadelphia: University of Pennsylvania Press, 2006).

9. "The Road to Soth African Freedom," South African Communist Party, (1962), retrieved from https:// www.marxists.org/history/international/comintern/sections/sacp/1962/road-freedom.htm.

10. Bryan Roby, The Mizrahi Era of Rebellion: Israel's Forgotten Civil Rights Struggle 1948-1966, (Syracuse, NY: Syracuse University Press, 2015).

11. Sami Shalom Chetrit, Intra-Jewish Conflict in Israel: White Jews, Black Jews, (London and New York, NY: Routledge, 2009).

12. Jewish Dissident, "The Olga Document," Blogger.com, (May 28, 2018), retrieved from https://jewishdissident.blogspot.com/2018/05/the-olga-document.html.

13. "The Haifa Declaration," Mada al-Carmel, (May 15, 2007), retrieved from https://mada-research.org/ en/files/2007/09/haifaenglish.pdf.

14. "The Future Vision of the Palestinian Arabs in Israel," The National Committee for the Heads of The Arab Local Authorities in Israel, (2006), retrieved from http://www.adalah.org/newsletter/eng/dec06/tasawor-mostaqbali.pdf.

15. Naseer Aruri, Palestinian Refugees: The Right of Return, (Sterling, VA: Pluto, 2001). 